\title{
Research and Policy Suggestions on Promoting the Greenization of the Lifecycle of Automobile Products
}

\author{
Wang Jia ${ }^{1, *}$, Huo Lulu ${ }^{1}$, Huang Yonghe ${ }^{1}$, Liu Bin ${ }^{1}$, Li Yuke ${ }^{1}$, Pan Wei ${ }^{1}$, Li Zhenbiao ${ }^{1}$ and Shi Hong ${ }^{1}$ \\ ${ }^{1}$ China Automotive Technology \& Research Center Co., Ltd. (CATARC)
}

\begin{abstract}
The greenization of product cycle is the current development trend. Production and consumption are two important links in the lifecycle of automobiles. Therefore, these two links play an important role during the promotion of the greenization of the lifecycle. Through carrying out the evaluation of the environmental benefits of the automobile air conditioning refrigerant alternatives and the analysis of the implementation effect of the automobile taxation scheme, this paper makes suggestions of the greenization of the production and consumption links, thus accelerating the progress of the lifecycle.
\end{abstract}

\section{OVERVIEW}

In the promotion of the greenization of the lifecycle of automobiles, production and consumption are two key links. This paper selects the automobile air conditioning refrigerant alternatives and the reform of the green tax system as the key contents at the production and consumer sides respectively, studies how to carry out the greenization, and proposes relevant policy suggestions.

At present, the third-generation of refrigerant HFC134a (R134a for short) is used in automobile air conditioning in China. However, due to its severe greenhouse effect, countries are planning to reduce its use gradually. Factors such as safety, environmental protection, performance, and economy should be considered for the alternatives of refrigerants, and comprehensive considerations should be made.

Taxation is one of the main tools and the means of the government to regulate social and economic activities. Tax policies can effectively guide energy conservation and environmental protection. In view of the important role of automobile products in energy consumption and pollutant emissions, increasing countries have begun to establish and improve the tax system that aims to promote energy conservation and emission reduction of automobile products, namely the green automobile tax system. Presently, the guiding function of China's automobile tax system for energy conservation and emission reduction is insufficient. It is urgent to establish a green tax system to promote the greenization of automobile products consumption.

\section{Evaluation Methods of the Environmental Benefits of the Automobile Air Conditioning Refrigerant Alternatives}

\subsection{Considerations for alternative refrigerant selection}

In the selection of refrigerant alternatives, factors to be considered comprehensively include: safety (toxicity, flammability), environmental protection (GWP value, ODP value, LCCP value), performance (physical property, energy efficiency, reliability) and economy (technical innovation cost, system cost, patent cost), etc. How to balance the contradictions between these requirements is one of the main issues in the future development of refrigerant alternatives ${ }^{[1]}$.

\subsection{Life cycle analysis of automobile air conditioning refrigerant alternatives}

At present, the evaluation methods of the reduction effect of refrigerants include: 1)Evaluate directly with GWP; 2)Consider the CO2 ERR filled by the system; 3)Consider the evaluation method of TEWI impacted by the system operation energy consumption; 4)Consider the LCCP method impacted by the lifecycle of the refrigerants.

This paper selects LCCP as the evaluation indicator while analyzing the environmental benefits of automobile air conditioning, analyzes R134a, R152a, R1234yf and R744.

The analysis of the Life Cycle Climate Performance (LCCP) of automobile air conditioning systems can be divided into two parts: direct emissions and indirect emissions. The direct emissions are caused by the direct leakage of the refrigerant into the atmosphere during the 
refrigerant filling, air conditioning operation, maintenance, and recycling, resulting in the greenhouse effect; the indirect emissions refer to greenhouse gas emissions due to energy consumption during the manufacturing, transportation, use, and recycling of automobile air conditionings and refrigerants. The specific calculation process of LCCP is shown below. Each part is measured in the form of equivalent $\mathrm{CO} 2$ emissions.

$$
L C C P=G W P \times A \times n+E \times n+F+G
$$

Wherein, A represents the direct leakage of refrigerant, including the annual conventional leakage, the annual unconventional leakage, and the leakage of other links; E represents the indirect emissions of annual energy consumption of air conditioning operation; F represents indirect emissions of energy consumption for the production and recycling of the refrigerants; $G$ represents indirect emissions of energy consumption for the production and recycling of the air conditioning systems; and $\mathrm{n}$ represents the service life of the automobile, which is 12 years.

Based on the research results and relevant references ${ }^{[2-}$ 6], the LCCP values and proportions of the four refrigerants, R134a, R152a, R1234yf, and R744, are calculated, please refer to Table 4 and Table 5.

Table 1. Comparison of four refrigerants LCCP ( $\mathrm{kg}$ carbon equivalent)

\begin{tabular}{|c|c|c|c|c|}
\hline \multirow{2}{*}{ Refrigerant } & \multirow{2}{*}{ Direct emission } & \multicolumn{2}{|c|}{ Indirect emission } & \multirow{2}{*}{ LCCP } \\
\cline { 3 - 4 } & & $\begin{array}{c}\text { Total indirect } \\
\text { emissions }\end{array}$ & $\begin{array}{c}\text { Wherein, indirect } \\
\text { emissions from operations }\end{array}$ & \\
\hline R134a & $1,080.00$ & $6,937.08$ & 6,900 & $8,017.07$ \\
\hline R152a & 76.06 & $6,661.08$ & 6,624 & $6,737.14$ \\
\hline R1234yf & 2.43 & $7,213.08$ & 7,176 & $7,215.52$ \\
\hline R744 & 0 & $10,518.94$ & 10,488 & $10,518.94$ \\
\hline
\end{tabular}

The life cycle emissions of the four refrigerants are R744 $>$ R134a $>$ R1234yf $>$ R152a.

Table 2. Proportion of each part of four refrigerants LCCP (\%)

\begin{tabular}{|c|c|c|c|c|}
\hline \multirow[b]{2}{*}{ Refrigerant } & \multirow[b]{2}{*}{ Direct emission } & \multicolumn{2}{|r|}{ Indirect emission } & \multirow{2}{*}{$\begin{array}{l}\text { LCCP (kg carbon } \\
\text { equivalent) }\end{array}$} \\
\hline & & $\begin{array}{l}\text { Total indirect } \\
\text { emissions }\end{array}$ & $\begin{array}{l}\text { Wherein, the proportion of indirect } \\
\text { emissions from operations in total LCCP }\end{array}$ & \\
\hline R134a & 13.47 & 86.53 & 86.07 & 100 \\
\hline R152a & 1.13 & 98.87 & 98.32 & 100 \\
\hline R1234yf & 0.037 & 99.97 & 99.45 & 100 \\
\hline R744 & 0 & 100 & 99.71 & 100 \\
\hline
\end{tabular}

The proportion of emissions from fuel consumption in the lifecycle is R744>R1234yf $>$ R152a $>$ R134a.

With reference to the domestic average level, R134a, R152a, R1234yf and R744 are respectively adopted as the results of life cycle emissions of automobile air conditioning refrigerants, which are shown in Figure 1.

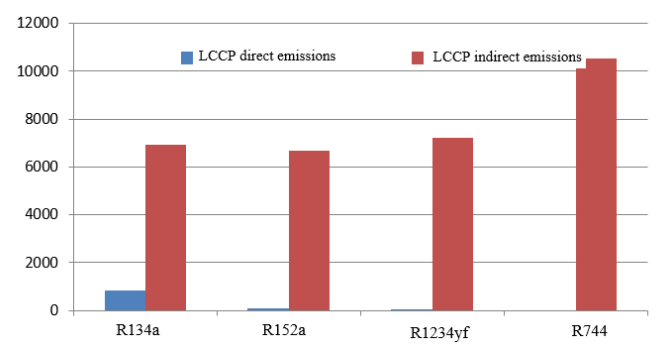

Figure 1. Life cycle emissions of different refrigerants $(\mathrm{kg}$ carbon equivalent)

\section{Green Automobile Tax System}

\subsection{Basic principles and key considerations for the establishment of the green automobile tax system}

Based on the basic principles of the tax system ${ }^{[7]}$, combined with the characteristics of automobile products and the goals of energy conservation and emission reduction policies, the establishment of the green automobile tax system should follow the following basic principles. 
Table 3. Basic principles for the establishment of the green automobile tax system

\begin{tabular}{|c|c|c|}
\hline Basic principles & Description & Key considerations \\
\hline $\begin{array}{c}\text { Tax neutrality } \\
\text { principle }\end{array}$ & $\begin{array}{c}\text { The adjustment of the tax system does not interfere with } \\
\text { economic operation; } \\
\text { focusing on regulating behaviors, taking the increasing of tax } \\
\text { revenues as the supplement; }\end{array}$ & $\begin{array}{c}\text { Guarantee the overall balance of } \\
\text { automobile taxation }\end{array}$ \\
\hline $\begin{array}{c}\text { Environmental } \\
\text { protection priority }\end{array}$ & $\begin{array}{c}\text { Environmental protection is the main policy goals of the } \\
\text { green tax system, and its energy conservation and emission } \\
\text { reduction guidance should be considered in the design of the } \\
\text { tax system }\end{array}$ & $\begin{array}{c}\text { Energy conservation and emission } \\
\text { reduction indicators should be } \\
\text { included in the automobile tax } \\
\text { system }\end{array}$ \\
\hline $\begin{array}{c}\text { Tax elasticity } \\
\text { principle }\end{array}$ & $\begin{array}{c}\text { Tax revenues should be able to be adjusted flexibly and } \\
\text { appropriately according to factors such as fiscal revenue and } \\
\text { expenditure, economic development, and taxpayers' } \\
\text { affordability }\end{array}$ & $\begin{array}{c}\text { A dynamic adjustment mechanism } \\
\text { should be set up for the design of } \\
\text { the tax system }\end{array}$ \\
\hline $\begin{array}{c}\text { Equity, efficiency } \\
\text { and coordination } \\
\text { principle }\end{array}$ & $\begin{array}{c}\text { The design of the tax system should not only improve } \\
\text { ecological efficiency, but also avoid generating negative } \\
\text { impacts on production and consumption; while ensuring } \\
\text { efficiency, the equity should also be considered at the same } \\
\text { time, and the equity should be achieved by internalizing the } \\
\text { external environmental costs of taxpayers }\end{array}$ & $\begin{array}{c}\text { Adjust based on the current tax } \\
\text { system, no new taxes will be added, } \\
\text { and the energy conservation and } \\
\text { emission reduction indicators } \\
\text { should be directly related to the } \\
\text { level of tax burden }\end{array}$ \\
\hline $\begin{array}{c}\text { Orderly } \\
\text { advancement } \\
\text { principle }\end{array}$ & $\begin{array}{c}\text { Goals and tasks should be clarified, key links should be } \\
\text { grasped, and the reform pace should be grasped to advance in } \\
\text { stages and steps }\end{array}$ & $\begin{array}{c}\text { The design of the tax system should } \\
\text { be a combination of short and long, } \\
\text { and implemented step by step }\end{array}$ \\
\hline
\end{tabular}

\subsection{Design of the green automobile tax system}

\subsubsection{Overall framework}

Based on the principles of tax neutrality and equity and efficiency, the establishment of the green automobile tax system in China should first ensure the overall balance of automobile taxation; secondly, the optimization and adjustment should be carried out based on the current automobile tax system and the regulating functions of the current taxes on energy conservation and environmental protection should be strengthened, and it is not suitable to add special environmental protection taxes.

\subsubsection{Selection of tax categories}

Consumption tax is levied on specific consumer products and specific consumption behaviors. Regulating consumption is one of the main goals of levying consumption tax. The levy of passenger car consumption tax based on displacement also considers the guiding role of energy conservation and emission reduction to a certain extent. Strengthening its guiding role of energy conservation and emission reduction based on this is also more reasonable. From the perspective of the amount of tax, the regulating role of the automobile purchase tax which is paid by consumers directly is significant. Therefore, the establishment of the green automobile tax system can focus on the adjustment of consumption tax and automobile purchase tax.

\subsubsection{Selection of energy conservation and emission reduction indicators}

At present, China has formulated, issued and implemented a series of important standards for test methods, limits and markings such as GB 19578 Fuel consumption limits for passenger cars and GB 27999 Fuel consumption evaluation methods and targets for passenger cars. Therefore, the inclusion of passenger car fuel consumption targets into the automobile tax system has already had a certain foundation, and passenger car fuel consumption targets of $100 \mathrm{~km}$ can be added based on the original tax system.

\subsubsection{Specific reform plans}

In order to promote the implementation of the policy as soon as possible, priority should be given to implementing preferential tax policies based on fuel consumption targets of passenger cars ${ }^{[8]}$. The specific plans are: For passenger cars that reach the target value of fuel consumption 2 years in advance, the automobile purchase tax should be reduced by $50 \%$, and the consumption tax should be reduced by $25 \%$; for passenger cars that reach the target value 2 years in advance and are over $20 \%$ better than the target value, the automobile purchase tax should be reduced by $75 \%$, and the consumption tax should be reduced by $50 \%$;

Table 4. Specific plans for the green automobile tax system

\begin{tabular}{|c|c|c|}
\hline $\begin{array}{c}\text { Fuel consumption } \\
\text { requirements }\end{array}$ & $\begin{array}{c}\text { Automobile } \\
\text { purchase tax }\end{array}$ & $\begin{array}{c}\text { Consumption } \\
\text { tax }\end{array}$ \\
\hline $\begin{array}{c}20 \% \text { better than the target } \\
\text { value 2 years in advance }\end{array}$ & $\begin{array}{c}\text { Be reduced by } \\
75 \%\end{array}$ & $\begin{array}{c}\text { Be reduced by } \\
50 \%\end{array}$ \\
\hline $\begin{array}{c}\text { Reach the target value } 2 \\
\text { years in advance }\end{array}$ & $\begin{array}{c}\text { Be reduced by } \\
50 \%\end{array}$ & $\begin{array}{c}\text { Be reduced by } \\
25 \%\end{array}$ \\
\hline
\end{tabular}

\subsection{Analysis on the implementation effect of the green automobile tax system}

Calculating with the passenger car fuel consumption data and sales data in 2018 as the benchmark, new energy 
vehicle models are basically better than the target value 2 years in advance. This preferential policy can be used as a springboard policy after the withdrawal of new energy vehicle's exemption from the purchase tax policy, which can effectively include the existing preferential policies for new energy vehicles into the green tax system.

Regardless of new energy vehicles, a total of $3 \%$ of the conventional fuel vehicles can enjoy preferential policies, of which about $1 \%$ of vehicle models' fuel consumption levels can be better than the target value 2 years in advance. This policy can effectively reduce the purchase cost of vehicle models with low fuel consumption and low emission.

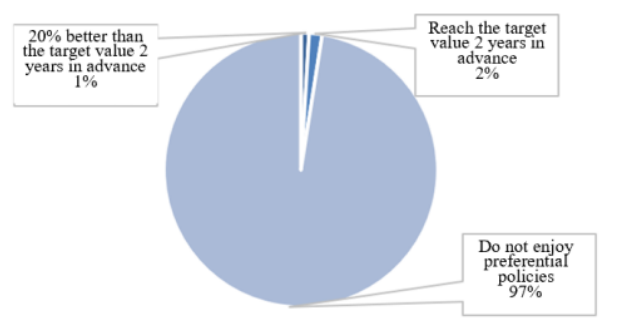

Figure 2. Fuel consumption of conventional fuel passenger cars in 2018 that reached the target value in 2020

Including new energy vehicles, the market proportion of passenger cars that enjoy preferential policies is over $7 \%$, covering about 1.4 million passenger cars. According to the theory of price elasticity of demand, the coefficient of price elasticity of demand $=$-the percentage of change in the demand amount/the percentage of price change. Calculating according to the historical automobile tax preferential policies, the elasticity coefficient of automobile demand price is -3.4. From this it can be calculated that the policy can drive the growth of the consumption of energy conservation and new energy vehicles of 400,000 . In consideration of the guiding role of technical requirements for enterprise technological progress, the actual driving effect of policies will be more obvious.

\section{Policy Suggestions on Promoting the Greenization of the Lifecycle of Automobile Products}

\subsection{Encourage and support research on alternative technologies with independent intellectual property rights}

At the current stage, it is very difficult to develop alternatives that can meet environment and safety requirements, and that are technically feasible and meet environment and safety requirements, and domestic research and application of alternative technologies for the automobile air conditioning refrigerant R134a are still insufficient. Therefore, it is suggested to encourage and support the development and research on alternatives and alternative technologies, and accelerate the replacement work of HFCs.

\subsection{Promote technological progress of air conditioning and vehicles}

In order to reduce the fuel consumption of automobile air conditioning, technological progress such as environmental protection, high efficiency, energy conservation, material saving, safety, and stability of automobile air conditioning should be actively promoted. For the new generation of environment-friendly vehicles, such as BEV, HEV, and other low-emission vehicles, since their power is much smaller than that of conventional powered vehicles, the power that can be provided to the air conditioning system is extremely limited. The energy-saving and high efficient air conditioning system with reliable performance should be further developed.

\subsection{Improve the green tax collection and management system}

Preferential tax policies are handled by tax authorities specifically. However, since the fuel consumption management system of passenger cars is involved in it, the taxation department should strengthen coordination and cooperation with the competent department of the automobile industry to form an information sharing and exchange mechanism, improve the tax supervision system, and ensure the authenticity and validity of fuel consumption data.

\subsection{Promote the reform of automobile consumption tax}

Taking the opportunity of consumption tax legislation, the reform of automobile consumption tax should be promoted actively. On the one hand, the consumption tax should be adjusted from the production link to the sales link to actually play its guiding role in energy conservation and emission reduction. On the other hand, the consumption tax should be changed from the central tax to the local tax or shared tax to increase the local fiscal revenue and guide local governments to increase capital investment in energy conservation and emission reduction.

\section{Acknowledgements}

This paper is supported by National Key Research and Development Program of China Solid Waste Resource Utilization Special Project -Automobile Products and Typical Parts Lifecycle Traceability System Design and Demonstration Application Research (2018YFC1902704).

\section{References}

1. Chen Wei, Qi Yingxia. Research progress and performance analysis on HCFCs alternative refrigerants. Chinese Journal of Refrigeration Technology, 39(12) 41-33; (2011)

2. The "Boustead Model", Life cycle analysis software, http://www.boustead consulting.co.uk/ 
3. Life Cycle Inventory Analysis of a Generic Vehicle, prepared by Ecobalance and University of Michigan, National Pollution Prevention Center for USAMP (U.S. Automotive Materials Partnership)(1998)

4. Mc Culloch A, Lindley A A. From mine to refrigeration: a life cycle inventory analysis of the production of $\mathrm{HFC}-134 \mathrm{a}[\mathrm{J}]$. International journal of refrigeration, 26(8): 865-872(2003)

5. Krieger, T. M.; Bateman, D. J.; Sylvester, R. W. Life Cycle Analysis for Production of HFC-134a and HFC-152a[R]. MAC Summit. Washington DC (2004).

6. Johnson, C. R. 744 as an Adjustment to GWP[R].MAC Summit, Washington DC, (2004).

7. Zuo Xiaolong. Green Tax Theory and the Construction of China's Green Tax System [D]. Baoding: Hebei University(2010).

8. Pang Pai. Current Situation Analysis and Reform Path of the Green Tax in China's Automobile Consumption Link [J]. Journal of Liaoning University of Technology (Social Science Edition), Issue 15:35-36(2019) 